Website: ijetms.in Issue:6, Volume No.4, September-2020 DOI: 10.46647/ijetms.2020.v04i06.009

\title{
The Relevance of Doubly - Fed Induction Generator (DFIG) in Modelling and Simulation of a Grid Connected Wind Turbine System
}

\author{
Samuel. A. Omolola ${ }^{1}$, Najeem O. Adelakun ${ }^{2}$ \\ ${ }^{1}$ Department of Electrical / Electronic Engineering, The Federal Polytechnic, Ilaro, Ogun State, Nigeria. \\ ${ }^{2}$ Department of Electrical / Electronic Engineering, The Federal Polytechnic, Ilaro, Ogun State, \\ Nigeria. ${ }^{1}$ saomolola@gmail.com \\ 2adelakunnajeemegmail.com
}

\begin{abstract}
The need for clean and stable electricity has given rise to renewable energy globally. Currently, Wind Energy generation is one the leading renewable energy sources and DFIG-based wind turbine are invariably the best approach to generate a multi-megawatts power at variable speed with less fluctuation in output power, ability to control its generated active and reactive power with minimal cost. This paper presents a model of a grid connected DFIG based Wind Turbine system for variable- speed where the speed range requirements are small, the overall system simulated using MATLAB/SIMULINK and the results shows the behaviour of DFIG with this type of control system and the numerous advantages in terms of cost reduction and the potential to build economically at multi-megawatt power system, as a result, DFIG grid connected wind turbine is essential.
\end{abstract}

Keywords — wind energy, DFIG, turbine, grid, electric power.

\section{INTRODUCTION}

The concerns about the greenhouse effect and intermittent conventional energy source have made renewable energy sources an alternative energy source to be implemented [2]. Wind energy is one of the leading renewable energy sources, it uses large blades to spin a dynamo inside the turbine which converts mechanical energy into electrical energy [9]. A Wind Farm is a set of Wind Turbines situated in the same location to generate electric power. Wind Turbines are designed such that they are operating with either constant or variable speed depending on the type of generators that are installed either singly-fed induction generator (SFIG) or doubly-fed induction generator (DFIG). Basically, there are three classes of generators that are used in modern wind turbine generating system (WTGS). These are Permanent Magnet Synchronous Generator (PMSG), Squirrel Cage Induction Generator (SCIG) and Doubly-Fed Induction Generator (DFIG). Both PMSG and SCIG are singly-fed induction generators (SFIG) and are similar in operation [10]. Doubly-Fed Induction Generator based Wind Turbine is better than
PMSG based Wind Turbine and SCIG based Wind Turbine systems because of DFIG improved efficiency, its ability to control torque [11], the approach will lead to low maintenance cost and also boost energy efficiency of electrical power output [14]. This work will be based on DFIG due to its flexibility and numerous advantages over the Singly-fed induction generator.

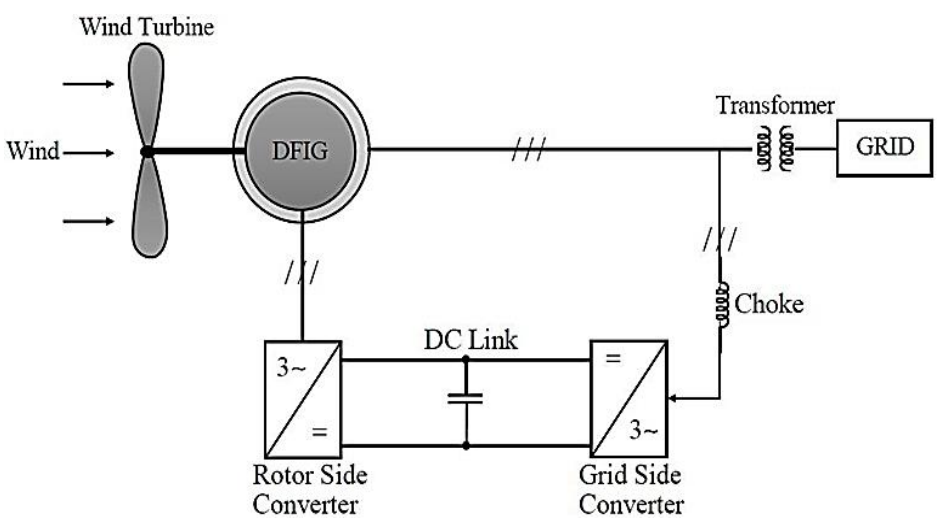

Fig. 1: Schematic diagram of DFIG-based wind energy systems. [6]

DFIG is a wound rotor induction machine in which its stator windings are connected to the grid and its frequency is locked with the frequency of the grid while its rotor windings are connected to the grid via a three - phase $\mathrm{AC} / \mathrm{DC} / \mathrm{AC}$ converter through slip rings [1], [3]. The rotor side converter controls the torque and the speed of the DFIG while the DC Link voltage is controlled by the grid side converter. When the wind speed is higher than the rated wind speed of the conversion system, both the stator and rotor of the DFIG supply active power to the grid, while when the wind speed is less than the rated wind speed, only stator winding supply power to the grid [12]. 
Website: ijetms.in Issue:6, Volume No.4, September-2020 DOI: 10.46647/ijetms.2020.v04i06.009

[8] compared the losses in different turbine systems such as the Direct-in-Line wind turbine system which is a singlyfed induction generator (SFIG) and Doubly-fed induction generator (DFIG) based wind turbine system. From the comparison of the losses, the authors showed that the losses in the generator for both Direct Line and DFIG are the same, $3.5 \%$ each but the inverter loss for Direct Line is 3\% while the inverter loss for DFIG is $0.75 \%$.

According to [4] the simulation result revealed that DFIG based wind turbine equipped with the PSS can damp power system oscillation better than synchronous generator with PSS. The authors stressed the importance of damping and also stated that poor damping of power oscillation and inadequate reactive power support can adversely affect the system stability and thereby affecting the quality of power supplied to the grid. Therefore, the authors argued that DFIG based wind turbine equipped with PSS can damp system oscillation of low - frequency power system more effectively than the synchronous generator with PSS.

Another paper presented by [7] Dynamic modelling and control of DFIG based wind turbines under balanced network conditions. The authors are of opinion that Doubly-Fed Induction Generators are similar to AC generators but have added features that make them operate at speed slightly below or above the synchronous speed which is useful for a large wind turbine with variable speed since the wind speed is random. The authors concluded that the MATLAB/SIMULINK simulations revealed the effectiveness of the control strategies. Similarly, [13] proposed a system that used STATCOM to achieve the reactive power obligation in order to stabilize the wind farm [13].

In view of all the numerous advantages of Doubly-Fed Induction Generator based Wind Turbine system over the Singly-Fed Induction Generator, it is pertinent to critically study and evaluate the working operation, control and performance of DFIG in order to adequately inform the user and the utility provider of the renewable energy from wind turbine system the uniqueness and unsurpassed cost effectiveness of DFIG.

\section{METHODOLOGY}

The Wind Farm-DFIG Detailed model of the MATLAB/SIMULINK was adopted and some modifications were made to the adopted model. The blocks on the model were selected from the Simulink library, and the initial state vector was regenerated to avoid error in the Simulink when the model was run. Several parameters were considered in the design specifications of this work. These include Turbine Specifications, Generator Specifications, Converter Specifications, control blocks parameters and Drive train data for wind turbine.

\section{A. Turbine Specification}

The Wind Turbine is DFIG-based wind turbine system.

Number of Wind Turbines $=6$

Data for 1 Wind Turbine are:

Nominal mechanical output power $(\mathrm{W})=1.5 \times 10^{6}=1.5 \mathrm{MW}$

Total Output Power for the 6 Wind Turbines $=6 \times 1.5$ $=9 \mathrm{MW}$

Wind speed at nominal speed and at $\mathrm{C}_{\mathrm{P}} \max$ (between $6 \mathrm{~m} / \mathrm{s}$ $-30 \mathrm{~m} / \mathrm{s})=11 \mathrm{~m} / \mathrm{s}$

Initial wind speed $(\mathrm{m} / \mathrm{s})=11$

\section{B. Generator Specification}

Generator data for 1 Wind Turbine are:

Nominal Power $(\mathrm{VA})=1.5 \times 10^{6} / 0.9=1.67 \times 10^{6}=1.67 \mathrm{MVA}$

Power factor $(\mathrm{pf})=0.9$ lagging

Nominal line-to-line voltage $\left(\mathrm{V}_{\mathrm{rms}}\right)=575 \mathrm{~V}$

Nominal Supply Frequency $=50 \mathrm{~Hz}$

Stator resistance $R_{S}=0.023 p u$ based on the generator ratings

Leakage inductance $\mathrm{L}_{S}=0.18 \mathrm{pu}$ based on the generator ratings

Rotor resistance $\mathrm{R}_{\mathrm{r}}{ }^{1}=0.016 \mathrm{pu}$ based on the generator ratings and referred to the stator.

Rotor Leakage inductance $\mathrm{L}_{\mathrm{r}}^{1}=0.16 \mathrm{pu}$ based on the generator ratings referred to the stator

Magnetizing inductance $\mathrm{L}_{\mathrm{m}}=2.9 \mathrm{pu}$ based on the generator ratings

Inertia constant $\mathrm{H}(\mathrm{s})=0.685$

Friction factor $\mathrm{F}(\mathrm{pu})=0.01 \mathrm{pu}$ based on the generator ratings

Pole pairs $\mathrm{p}=3$

Initial conditions are:

Initial slip $\mathrm{s}=-0.3$

Electrical angle $\phi($ degree $)=0^{0}$

Magnitude of stator currents (pu) $\mathrm{i}_{\mathrm{as}}, \mathrm{i}_{\mathrm{bs}}, \mathrm{i}_{\mathrm{cs}}=0,0,0$

Phase angle of stator current (degree) $=0,0,0$

Total Nominal Power for the 6 generators $=6 \times 1.667 \mathrm{x}$ $10^{6} \mathrm{VA}=10 \mathrm{MVA}$ 
Website: ijetms.in Issue:6, Volume No.4, September-2020 DOI: 10.46647/ijetms.2020.v04i06.009

\section{Converter Specifications}

Number of wind turbines $=6$

Data for Converters for 1 Wind Turbine:

Maximum Current for Grid side converter $=0.8 \mathrm{pu}$ of generator nominal current

Grid side coupling inductor $=0.3 \mathrm{pu}$

Grid side coupling inductor resistance $=0.003 \mathrm{pu}$

Nominal DC - Link bus voltage $=1150 \mathrm{~V}$

Capacitance of DC - Link bus capacitor $=10000 \times 10^{-6} \mathrm{~F}$

Quality-factor $\mathrm{Q}=50$

Line filter capacitor $($ Var $)=120 \times 10^{3}$

\section{Drive train Specifications}

Number of wind turbines $=6$

Data for Drive train for 1 Wind Turbine

Wind turbine inertia constant $\mathrm{H}(\mathrm{s})=4.32 \mathrm{MW} / \mathrm{MVA}$

Shaft spring constant refers to high speed shaft $=1.11 \mathrm{pu}$ of nominal mechanical torque/rad.

Shaft mutual damping $=1.5 \mathrm{pu}$ of nominal mechanical
Turbine initial speed $=1.2 \mathrm{pu}$ of nominal speed

Initial Output torque $=0.83 \mathrm{pu}$ of nominal mechanical torque.

\section{E. Control Parameters}

Number of wind turbines $=6$

Control Parameters for 1 wind turbine

DC bus voltage regulator gains: $\mathrm{k}_{\mathrm{p}}=8 ; \mathrm{k}_{\mathrm{i}}=400$

Grid side converter current regulator gains: $\mathrm{k}_{\mathrm{p}}=0.83 ; \mathrm{k}_{\mathrm{i}}=5$

Speed regulator gains: $\mathrm{k}_{\mathrm{p}}=3 ; \mathrm{k}_{\mathrm{i}}=0.6$

Rotor side converter current regulator gains: $\mathrm{k}_{\mathrm{p}}=0.6 ; \mathrm{k}_{\mathrm{i}}=8$

Reactive power $\mathrm{Q}$ regulator gain $\mathrm{k}_{\mathrm{i}-\mathrm{var}}=0.05$

Voltage $\mathrm{V}$ regulator gain $\mathrm{k}_{\mathrm{i} \text {-volt }}=20$

Pitch compensation gains: $\mathrm{k}_{\mathrm{p}}=3 ; \mathrm{k}_{\mathrm{i}}=30$

PWM Carrier Frequency of the Grid side $(\mathrm{Hz})=2700$

PWM Carrier Frequency of the Rotor side $(\mathrm{Hz})=1620$

Source: [5]

\section{RESULTS AND DISCUSSION} torque/pudw

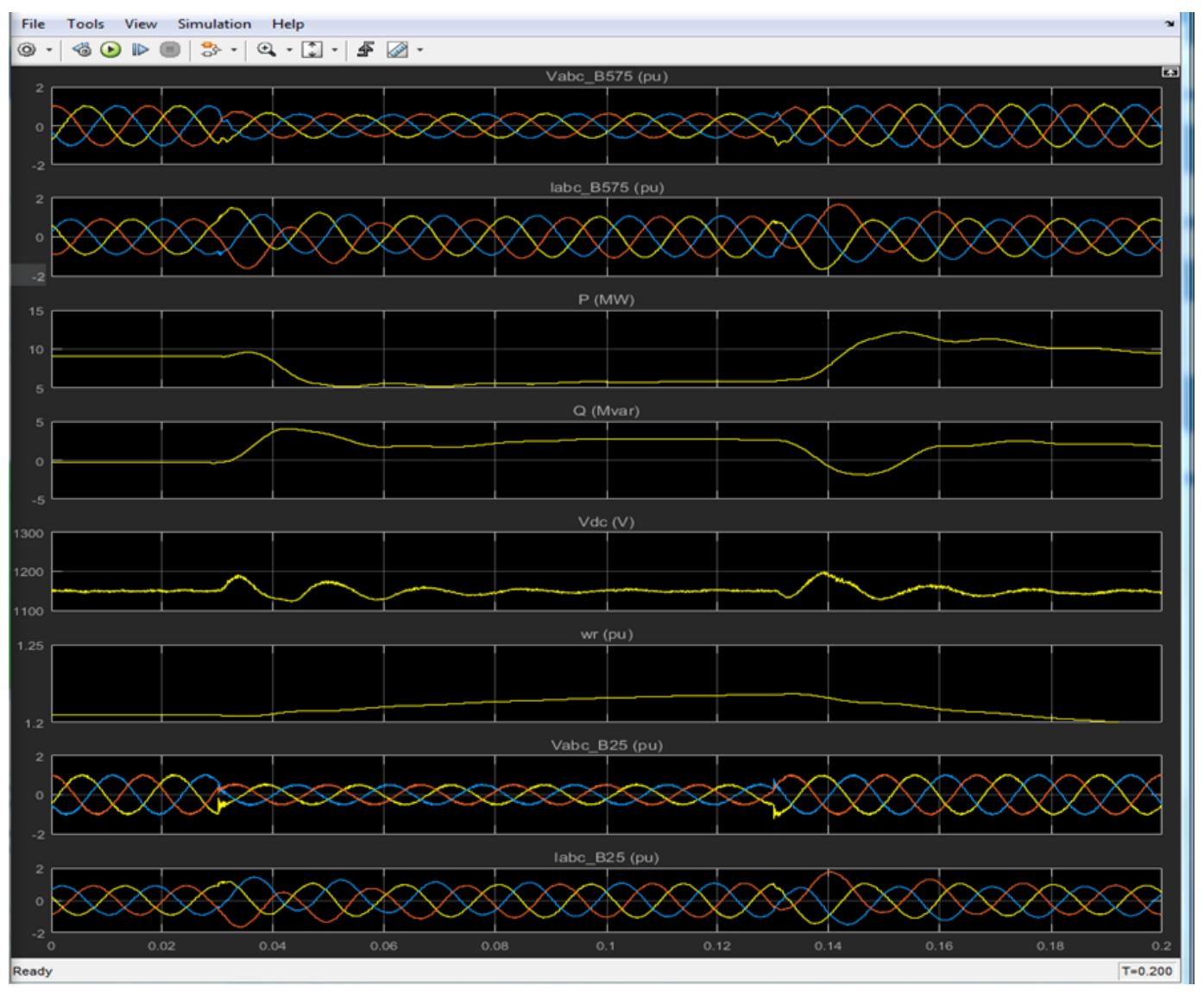

Fig 2: Simulation result for the wind farm when the wind speed is $15 \mathrm{~m} / \mathrm{s}$ 
Website: ijetms.in Issue:6, Volume No.4, September-2020 DOI: 10.46647/ijetms.2020.v04i06.009

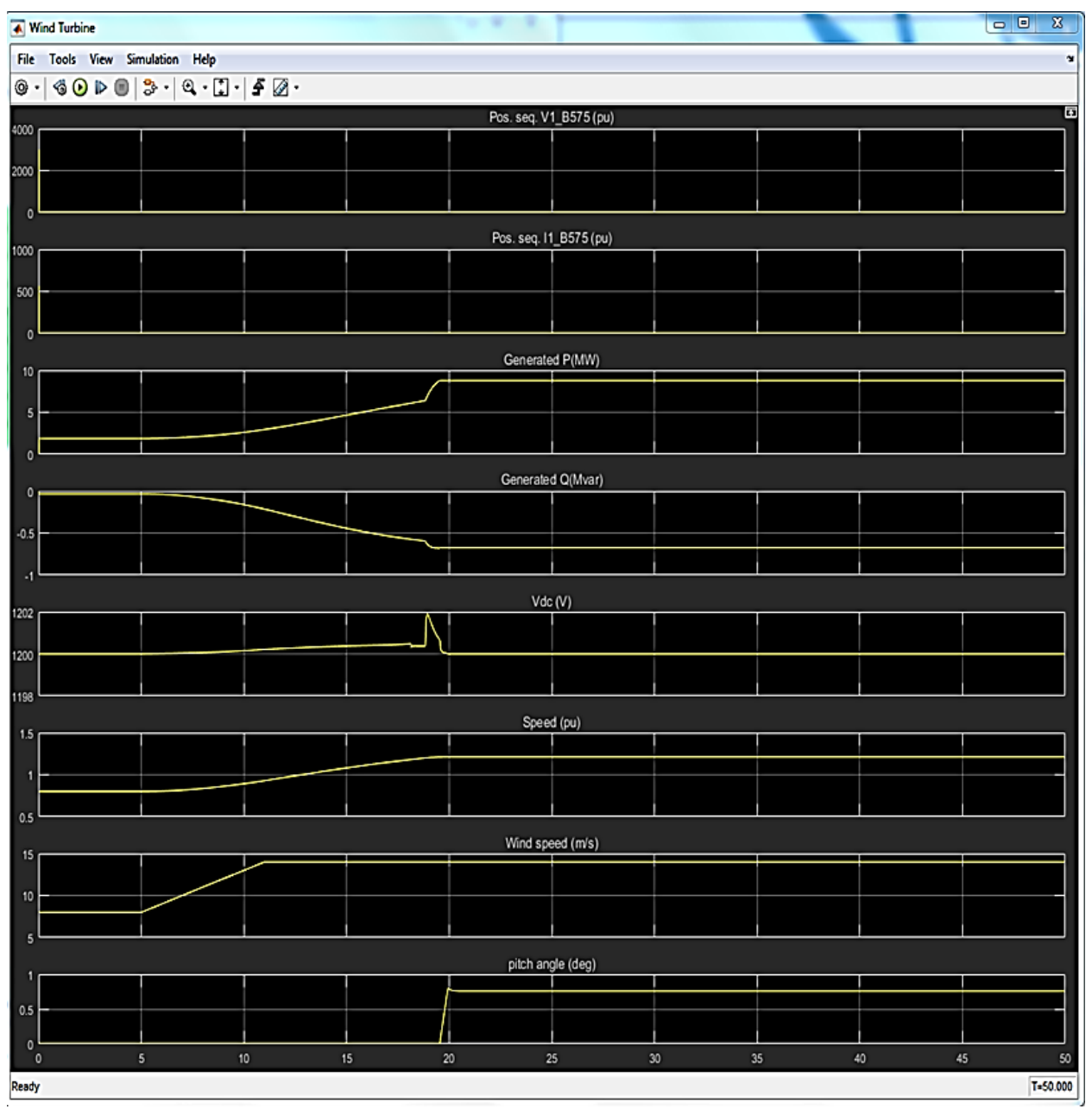

Fig. 3: Simulation result of Wind Farm connected to the Distribution network in Var regulation mode. 
Website: ijetms.in Issue:6, Volume No.4, September-2020 DOI: 10.46647/ijetms.2020.v04i06.009

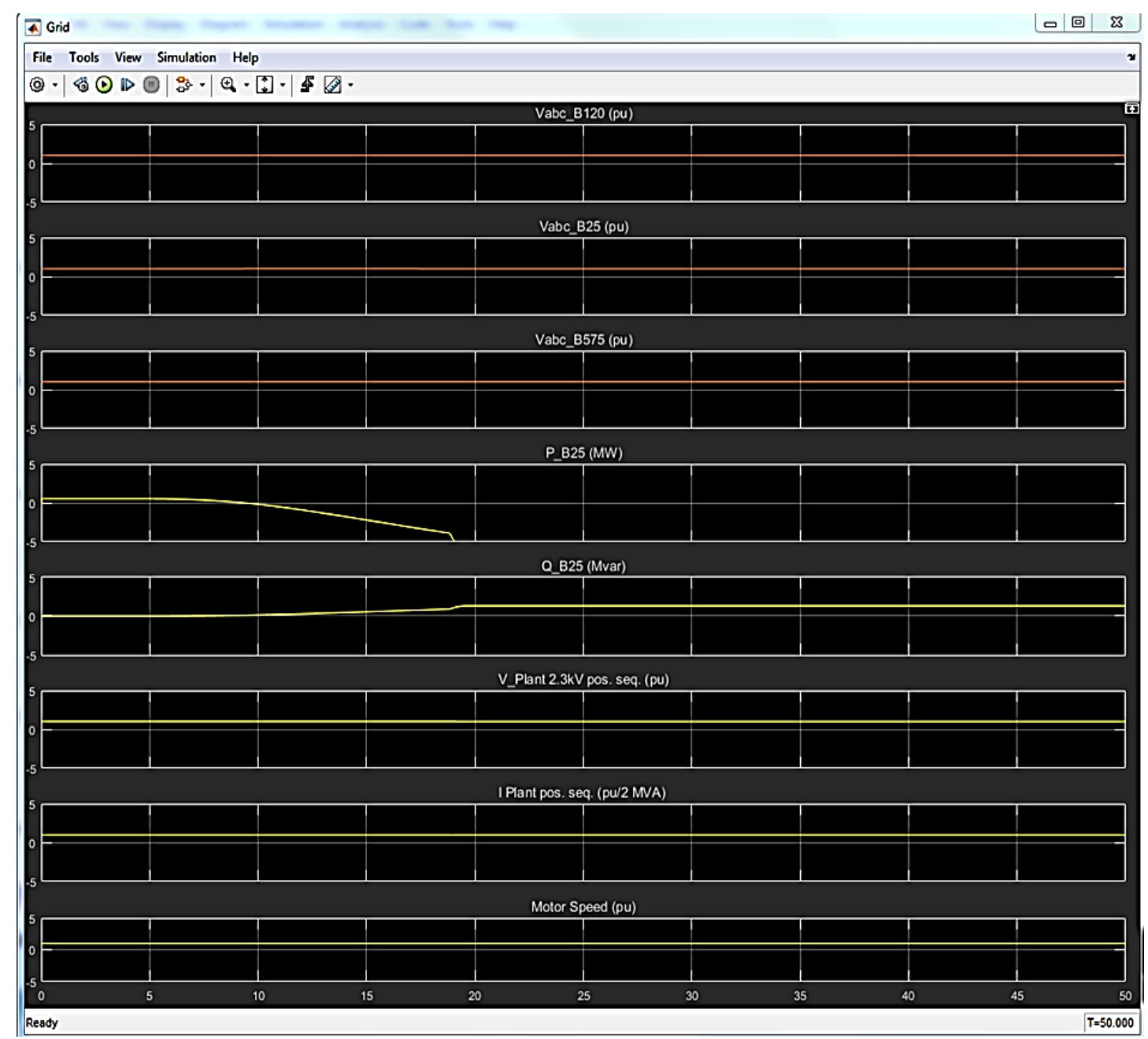

Fig. 4: Simulation result of Wind Farm connected to the Distribution network with short circuit fault at 10km from the grid.

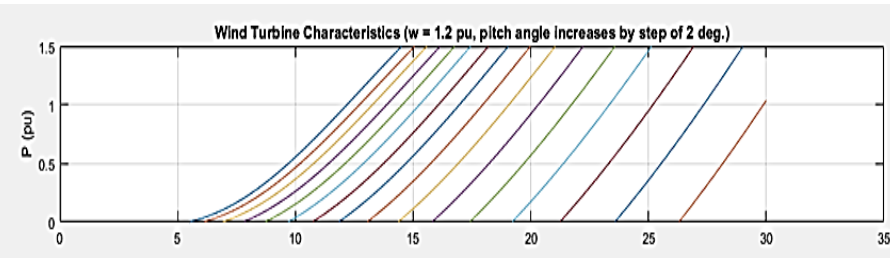

Fig. 5: Plot of Output power (pu), Tip Speed - Ratio $(\lambda)$ and Power Coefficient $\left(\mathrm{C}_{\mathrm{P}}\right)$ against Wind Speed $(\mathrm{m} / \mathrm{s})$.
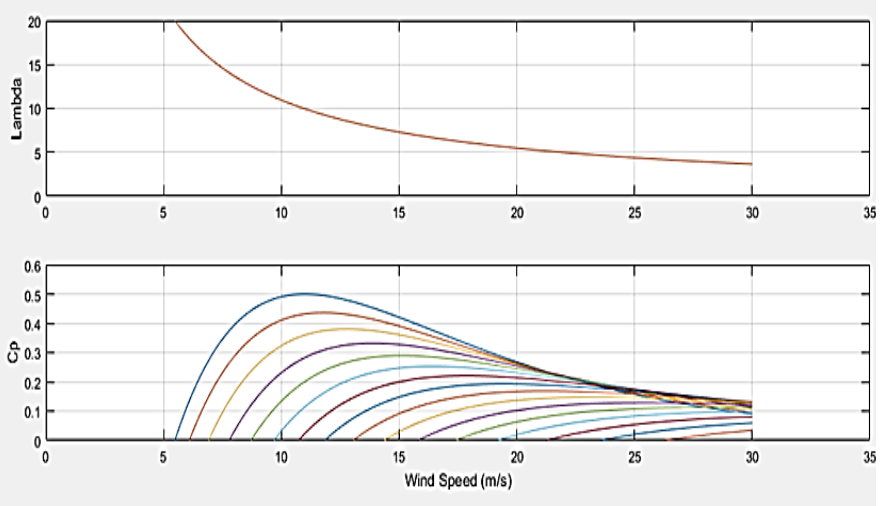
Website: ijetms.in Issue:6, Volume No.4, September-2020 DOI: 10.46647/ijetms.2020.v04i06.009

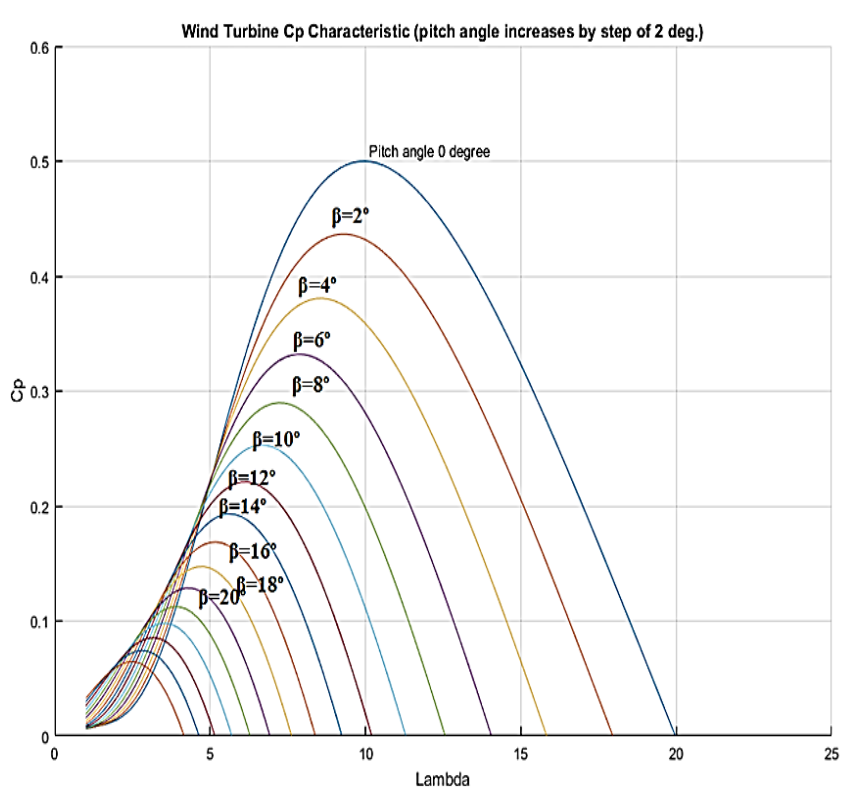

Fig. 6: Wind Turbine Power Coefficient Characteristics plot

Fig. 3 above shows the performance of DFIG based wind turbine when the wind speed varied between $8 \mathrm{~m} / \mathrm{s}$ and $14 \mathrm{~m} / \mathrm{s}$ respectively. The wind speed was initially set at $8 \mathrm{~m} / \mathrm{s}$ which is the minimum speed operation for the turbine, it should be noted that at a speed below the minimum speed operation, the turbine will stop working, and at time $\mathrm{t}=$ 5 seconds, the wind speed suddenly increases to $14 \mathrm{~m} / \mathrm{s}$ and the generated real power begins to rise gradually, as the wind speed rises to $9 \mathrm{MW}$ which is its rated value in approximately 18 seconds. Within this time interval, the turbine speed increases from $0.8 \mathrm{pu}$ of generator synchronous speed to $1.21 \mathrm{pu}$ of generator synchronous speed.

The pitch angle $\beta$ of the blade of the turbine was initially at $0^{0}$ (zero degree) and the wind turbine operating path follows the Tracking Characteristics region (optimum region) up to point $\mathrm{D}$ on the turbine power characteristics plot and to limit the mechanical output power, the pitch angle was set at $0.0133 \mathrm{rad}\left(\right.$ or $0.76^{\circ}$ ). The voltage at the grid and the generated reactive power were also monitored, the reactive power was regulated to keep the voltage at $1 \mathrm{pu}$.

Since 1 Wind Turbine produces $1.5 \mathrm{MW}$ at 1.67MVA which gives 0.9 power factor.

$\mathrm{Pf}=\cos \phi=0.9$ $\therefore \phi=\cos ^{-1}(0.9)=25.84^{0}$ lagging

$1.67\left\llcorner 25.84^{0}=1.50+\mathrm{j} 0.73\right.$ (Converting the Polar to Rectangular form)

Therefore, the wind turbine absorbs $0.73 \mathrm{MVar}\left(\mathrm{Q}_{\text {Generated }}=\right.$ $-0.73 \mathrm{MVar}$ ) at the nominal power to maintain the voltage constant. But when the mode of operation was changed to Var regulation and the reactive power $\mathrm{Q}$ was set to zero (0 Var), it was observed that the voltage increases from $1 \mathrm{pu}$ to $1.021 \mathrm{pu}$ at the nominal power generation of the turbine when the power factor is unity.

Fig. 6. shows the plot of Wind Turbine Power coefficient characteristics as a function of Tip Speed Ratio $\lambda$ and Pitch angle $\beta$. The power coefficient plot as a function of TSR and Pitch angle is a nonlinear graph such that as the pitch angle $\beta$ increases, the power coefficient $C_{P}$ decreases thereby reducing the power produced by the wind turbine. From the plot, the power coefficient is maximum when the pitch angle is zero degree $\left(0^{0}\right)$ and from equation (1), the turbine output power can be determined.

\section{CONCLUSION}

The relevance of Wind turbine system equipped with a Doubly-Fed Induction Generator (DFIG) was analysedusing the MATLAB / SIMULINK application, and the result shows that DFIG system displays numerous advantages which include cost reduction and it also possesses the potential to be built economically at multimegawatt power level. A load angle technique was developed to control the active and reactive power generated by the DFIG. The DFIG makes a significant contribution to grid voltage support during short circuit periods, the doubly - fed induction generator proved to be a more stable and dependable system when connected to the grid side with appropriate converter control systems. However, it is noted that DFIG based wind turbine reinforced with power system stabilizer damp system oscillation of low frequency excellently when compared to synchronous generator reinforced with power system stabilizer.

\section{References}

[1] Abomahdi, M. A. and Bharadwaj, A. K. 2015. Modeling and Simulation of DFIG to Grid Connected Wind Power Generation Using MATLAB, IAEME International Journal of Electrical Engineering and Technology (IJEET), Vol. 6, Issue 1, January 2015, Pp 29-40 
Website: ijetms.in Issue:6, Volume No.4, September-2020 DOI: 10.46647/ijetms.2020.v04i06.009

[2] Adelakun, N. O. and Olanipekun, B. A. 2019. A Review of Solar Energy," Journal of Multidisciplinary Engineering Science and Technology (JMEST), Vol. 6 Issue 12, December 2019, Pp 11344 $-11347$.

[3] Awasthi, A.; Diwan, R. and Awasthi, M. 2013. Study for Performance Comparison of SFIG and DFIG Based Wind Turbines, International Journal of Latest Trends in Engineering and Technology (IJLTET), 2(4).

[4] Edrah, M.; Kwok, L. L. and Anaya-Lara, O. 2016. Reactive power control of DFIG wind turbines for power oscillation damping under a wide range of operating conditions", The Institution of Engineering and Technology (IET).

[5] Gagnon, R.; Saulnier, B. and Forcione, A. (Hydro-Quebec) 2016. Wind Farm Using Doubly-Fed Induction Generators. MATLAB/SIMULINK",

[6] Izanlo, A., Gholamian, S. A. and Kazemi, M. V. 2017. Direct Power Control of a DFIG - Based Wind Turbine Under Unbalanced Grid Voltage Without Rotor Position Sensor, IIUM Engineering Journal, Vol. 18, No. 1,

[7] Mehdipour, C.; Hajizadeh, A. and Mehdipour, I. 2016. Dynamic modelling and control of DFIG - based wind turbines under balanced network conditions, ELSEVIER, 83, 60-569.

[8] Muller, S.; Deicke, M. and De-Doncker, R. W. 2002. Doubly Fed Induction Generator Systems for Wind Turbines. IEEE Industry Applications Magazine.

[9] Olanipekun, B. A. and Adelakun. N. O. 2020. Assessment of Renewable Energy in Nigeria: Challenges and Benefits, International Journal of Engineering Trends \& Technology (IJETT), Vol. 68, Issue 1. Jan 2020, Pp 64 - 67,

[10] Omolola S. A. and Alausa Dele W. S. 2018. The Effect of DoublyFed Induction Generator (DFID) Based Wind Turbine and Its Application, IISTE Journal of Energy Technologies and Policy, Vol.8, No.3,

[11] Omolola S. A. 2017. The Study and Modelling of Doubly-Fed Induction Generator (DFIG) based Wind Turbine and its Application, M.Sc. Thesis, Faculty of Engineering and Computing, Coventry University, United Kingdom.

[12] Santhosh, R. R. and Meenakshy, K. 2016. A Unique Grid Power Controller for DFIG Based Wind Turbine Generator System with or without Battery Storage Device. International Journal of Innovative Research in Science, Engineering and Technology, 5(5).

[13] Kumar V.; Patel V.; Pandey A. S.; Sinha S. K. and Kumar Dilip. 2018. Transient Stability Enhancement of DFIG based Offshore Wind Farm Connected to a Power System Network using STATCOM, International Journal of Engineering \& Technology7(3.12). 2018. Pp 1303-1311.

[14] Okoye, C. U. and Adelakun, N. O.2019. Design and Evaluation of Electrical Services for an Energy Efficient Home, Iconic Research and Engineering Journals, Vol. 3, Issue 6, Pp 95 - 102 